Vol. 18, n² | 2014

Varia

\title{
Toward a Global History of Homicide and Organized Murder
}

\section{Pieter Spierenburg}

\section{(2) OpenEdition \\ Journals}

Electronic version

URL: http://journals.openedition.org/chs/1492

DOI: $10.4000 /$ chs. 1492

ISSN: 1663-4837

\section{Publisher}

Librairie Droz

\section{Printed version}

Date of publication: 1 October 2014

Number of pages: $99-116$

ISBN: 978-2-600-01854-8

ISSN: $1422-0857$

\section{Electronic reference}

Pieter Spierenburg, «Toward a Global History of Homicide and Organized Murder », Crime, Histoire \& Sociétés / Crime, History \& Societies [Online], Vol. 18, n² | 2014, Online since 01 October 2017,

connection on 30 April 2019. URL : http://journals.openedition.org/chs/1492 ; DOI : 10.4000/chs.1492

(c) Droz 


\title{
Toward a Global History of Homicide and Organized Murder
}

\author{
Pieter Spierenburg ${ }^{12}$
}

The three contributions about China in this issue result from a workshop held in May 2012. This meeting formed part of a much larger enterprise that ultimately dates back to a research plan conceived by Eric Johnson and myself in 2006. Our original idea was to combine our respective interests - Nazi terror including the Holocaust and the general history of murder - and to extend the combination with a global perspective without chronological bounds. From the outset we realized that this involved a collective enterprise that needed generous funding. The latter has proven to be rather difficult. We did acquire funds to organize a meeting, in 2007, bringing together a set of experts on violence throughout the history of Latin America. With the additional support of Xavier Rousseaux, Marianna Muravyeva and James Sharpe, we could hold a series of somewhat smaller-sized meetings from late 2010 to the end of 2012. ${ }^{3}$ Major publications, before this issue of CHS, are a dossier of articles focusing on pre-modern Latin America ${ }^{4}$ and a collective volume on violence in modern Latin America, both edited together with Ricardo Salvatore. ${ }^{5}$ For the arguments outlined in this brief essay I must be solely responsible.

Given these two sets of articles and the ones in this issue, there is no need to include in the present essay a discussion of the history of either Latin America or China. I will, however, build further on our introduction to the dossier on

1 Emeritus Professor of Erasmus University (hosted by Department of Criminology). Program Leader at Institute for War and Genocide Studies (NIOD), Amsterdam. Selected publications: The Spectacle of Suffering: Executions and the Evolution of Repression: From a Preindustrial Metropolis to the European Experience, Cambridge (Cambridge UP) 1984 (reprinted as paperback 2008); The Prison Experience: Disciplinary Institutions and their Inmates in Early Modern Europe, New Brunswick, London (Rutgers UP) 1991 (reprinted by Amsterdam University Press 2007); Written in Blood: Fatal Attraction in Enlightenment Amsterdam, Columbus (Ohio State University Press) 2004; A History of Murder: Personal Violence in Europe from the Middle Ages to the Present, Cambridge (Polity) 2008; Violence and Punishment: Civilizing the Body through Time, Cambridge (Polity) 2012.

2 This essay is a condensed version of my plenary lecture at the meeting of Finnish historians, Helsinki, October 2012 and my presentation at the project's (see note 2) fourth meeting in York, 30 November 2012. Written in early 2014, it is updated with publications that appeared in 2012 and 2013. I am grateful to Philip Dwyer and Peter Romijn for their comments on the draft.

3 This series included a separate meeting on European homicide, financed by the GERN, Brussels October 2010 and a set of four meetings under the label The Global Trajectory of Murder and Genocide, financed mainly by the Netherlands Organization for Scientific Research (NWO): Rotterdam, April 2011; Rotterdam, November 2011; Helsinki, May 2012; and York, November 2012. These meetings are referred to in this text as $1^{\text {st }}-4^{\text {th }}$ meeting where references to contributions are given.

4 Johnson et al. (2012); Gabbert (2012); Dodds Pennock (2012); Few (2012).

5 Johnson et al. (2013). 
pre-modern Latin America. Besides sketching a European and global context for Latin American violence, that introduction contains several methodological and theoretical considerations. The present essay purports to do three things: to provide an update of the original research question; to discuss briefly what I think we know so far; to reflect on the remaining methodological and theoretical problems.

The basic idea behind the original research question is the conviction that it helpful for scholarship to distinguish ordinary from out of the ordinary killing, or homicide from something more massive. Morally, this distinction may or may not be relevant. It suffices that it is relevant for research and our subsequent understanding - an understanding that might be helpful in making plans for reducing violence in the world. The distinction in question is not between a single act and more. Homicide includes multiple murder, by bandits or serial killers for example, and vengeance, in which there are more often multiple perpetrators than multiple victims. When it comes to organized murder, the Holocaust is perhaps the best-known example, and in any case the most extensively researched. Alternatively, we may consider the events of 9/11. The fact that I can write just these two figures, convinced that everyone will understand, underlines the out-of-the ordinary character of this catastrophe. Indeed, the FBI, whose Uniform Crime Reports are a standard source for homicide researchers, kept the 9/11 data from its regular report over 2001: "The statistics of September 11 are not a part of the traditional Crime in the United States publication because they are different from the day-to-day crimes committed in this country. Additionally, combining these statistics with our regular crime report would create many difficulties in defining and analyzing crime as we know it."6

When ordinary and out-of-the-ordinary murders are kept separate, they must be analyzed separately. We measure the first as annual homicide rates per 100,000 population. In a big city like New York, a homicide happens every day, but society would break down if massive killing occurred anywhere at any time. Or, in more technical terms: any large enough area witnesses a certain number of homicides each year, but we rarely observe annually recurrent instances of organized murder. Hence, the latter cannot be counted in terms of annual rates. I am leaving for later the question which methodology we should apply. In addition, there are at least two theoretical reasons for studying homicide and organized murder separately. The first reason is relatively independent from the theoretical position that a scholar adopts. Whether or not an author agrees with Norbert Elias on the issue of civilizing processes, for example, he or she will consider homicide rates as reflecting the level of aggression in a population. By contrast, this is not necessarily always the case with organized murder. Obviously, even if the perpetrators of the attack on the World Trade Center had been New Yorkers, their actions would have revealed very little about the level of aggression among the city's population. From a different perspective, many perpetrators of the Holocaust have been described as bureaucrats, not particularly aggressive persons. Note that I am not arguing that organized murder never involves aggression. In contrast with a graph of homicide rates, however, there is no unambiguous answer to the question what an episode of mass killing represents.

The second theoretical reason for a separate study of organized murder has to do with another distinction, that between state violence and non-state violence. As I have argued on several occasions, homicide belongs to the category of non-state violence

[http ://www.fbi.gov/about-us/cjis/ucr/crime-in-the-u.s/2001/01sec5.pdf] (17 February 2014). 
and from the moment that it is possible to distinguish this category from its opposite, homicide can be meaningfully counted and analyzed. ${ }^{7}$ Of course state violence like executions, police shootings or casualties in war - can also be counted. Unlike with homicide, it is harder to situate organized murder into either one of these two categories. Consider the example of China in 1967-68, during the so-called 'cultural revolution'. Collective killings were concentrated in these two years. They had been ordered from above, but townships or villages decided on whom to kill, selecting the victims because of their family ties to former landlords and the like. ${ }^{8}$ In a similar vein, the terror from both the reds and the whites in the Russian civil war of 19171920 would have been impossible without a significant popular participation. ${ }^{9}$ In case of organized murder, we must conclude, the distinction between state violence and non-state violence often gets blurred. Note that this distinction is dissimilar to that between political and other violence. Organized murder often has a political dimension, but some individual homicides, too, are politically motivated.

Thus, there are methodological and theoretical reasons for studying organized murder and homicide separately. The two are not intrinsically different; killing is killing. Yet, the two must of necessity be studied in different ways. The reasons for preferring the concept of organized murder, especially over the alternative of genocide, are explained in Johnson et al. (2012): the unambiguous, legal character of the latter term is actually a disadvantage for research in the human sciences. ${ }^{10}$ Genocide both excludes certain cases of organized murder (against members of a specific social class, for example) and includes cases which are not murder such as, in Raphael Lemkin's original vision, the destruction of a culture ${ }^{11}$. The UN definition of genocide even includes changing a group's ethnicity through adoption and by this criterion the seventeenth-century Iroquois have been called genocidal. Although they did their share of killing non-combatants (women and children) from enemy tribes, they adopted most of their captives, some after torture. As a consequence, by the end of the seventeenth century more than half of the Iroquois nation consisted of persons originating from other tribes. ${ }^{12}$ The related concept of ethnic cleansing also has the disadvantage of including non-lethal activities, notably expulsion.

Johnson et al. ${ }^{13}$ further distinguish four types of reproachable mass mortality, proposing to include into the concept of organized murder two of them: (1) the conscious killing of civilians in times of war but relatively independent of military operations (to which I now add the killing of prisoners of war, who are no longer combatants) and (2) conscious killing without a state of war (but as a rule related to any type of socio-political conflict). It should be noted immediately that, the further one goes back in history, the more likely it is that non-combatants are women and children only. Our restrictive definition of organized murder excludes death in battle and 'collateral damage' in military operations as well as 'man-made' disasters such

See, among others, Spierenburg (2008, p. 2; 2012, pp. 7-9).

Yang Su at $3^{\text {rd }}$ Workshop.

9 Ludmila Novikova at $3^{\text {rd }}$ Workshop.

10 For the moment I am sticking to “organized murder", but Sémelin's and Dwyer's alternative of "massacre" would be worth further discussion.

11 Lemkin (1973 [1944]).

12 Blick in Moses ed. (2010, vol. 2, pp. 299-327).

13 Johnson et al. (2012). 
as famines indirectly resulting from political decisions. ${ }^{14}$ I realize that there is no consensus on this. Frank Dikötter's book on the Great Leap Forward in China, for example, has "great famine" in the title, which in the Dutch translation becomes massamoord (mass murder). Admittedly, some cases of starvation are purely deliberate. In German South-West Africa in 1904, Lothar von Trotha's troops drove the Herero into the desert after having destroyed or occupied the wells there. ${ }^{15}$ It would be nonsensical not to call this murder, also in view of explicit calls for the extermination of the Herero. In particular scholars who continue to employ the concept of genocide tend to include all types of 'man-made' famines into it. Since the capacity of leaders to issue measures that lead to mass starvation quickly diminishes as we go back in history, inclusion or exclusion of this type has a great effect on counting the victims of organized murder over time.

Finally, Johnson et $a l .{ }^{16}$ sketch a brief state of the art. For homicide this is the familiar story of long-term decline since the middle ages in many parts of Europe and a less marked decline in North America. For organized murder, a number of general studies, most of them employing the concept of genocide, were examined. These studies, often beginning with the extermination of the Herero, strongly suggest that genocidal murder belongs especially to the twentieth and now twenty-first centuries. We may additionally allow for a few episodes involving organized murder that began just before 1900, such as the policy of reconcentration in Cuba between 1895 and 1898 that cost the lives of an estimated $10 \%$ of the island's population. ${ }^{17}$ Consider also the well-researched 'rubber terror' in the Congo Free State since 1890, where the number of intentional killings is harder to estimate. ${ }^{18}$ The starting date for ethnic cleansing in Europe, moreover, is usually fixed at about $1870 .{ }^{19}$ Taking all this into account, we can maintain that the general literature about mass killing suggests that it was especially prevalent during the last 150 years.

This is intriguing, to say the least. The existing literature on the history of homicide and organized murder, respectively, yields two diametrically opposed conclusions. The long-term decline of homicide implies that the middle ages were much more violent than the twentieth century, whereas general studies of mass killing suggest that the last 150 years constitute the most violent period in history. The contradiction is easily explained, since both conclusions are based on incomplete research. As far as homicide is concerned, we know much about Europe and the United States but almost nothing about the non-Western world - including Eastern Europe. With respect to organized murder, for which the non-Western world does get due attention in the literature, the conclusion is based on a relative neglect of earlier periods. That mass killing is a typically modern phenomenon is strongly suggested but not proven.

14 The term 'man-made' is meant as gender-neutral, even though the role of female politicians in famines is negligible. The prototype of a 'man-made' famine, as already mentioned in Johnson et al. 2012, is the Holodomor in Ukraine.

15 Among many other publications : Zimmerer (2011, pp. 40-70).

16 Johnson et al. (2012).

17 Tone (2006).

18 Hochchild (1998); Schaller in Melber (2008, pp. 75-93); van Reybrouck (2010, p. 109). Compare Spierenburg (2013).

19 This applies, among others to Carmichael (2009), who combines the concepts of genocide and ethnic cleansing. She has a few pages on waves of persecution in Europe since the middle ages, but the real story begins in the late $19^{\text {th }}$ century. 
The suggestion, moreover, is implicit mainly in general studies of genocide. If we dig somewhat deeper, as I will show below, sufficient episodes of organized murder in earlier periods can be found. This was of course Eric Johnson's and my hunch when we started our project.

The body of the state of the art in Johnson et al. ${ }^{20}$ was written around 2010, just before the series of workshops referred to. This state of the art should be updated with some results of the workshops as well as studies published since 2010. In addition, a few works that originally escaped our attention are considered in the following section. For homicide I can report no substantial increase in our knowledge. We still know next to nothing about its incidence in the non-Western world and Eastern Europe going further back than the twentieth century. Available and reliable figures, analyzed in accessible languages, mostly date back no further than the 1920s and often the 1950s. The work of Thomas Buoye, present in this issue, constitutes one of the few exceptions. In an earlier book he had already shown that Chinese killers of the eighteenth century were tried and sentenced as a rule. ${ }^{21}$ This indicates that, as in Europe, the criminalization of homicide had been achieved in China by then. ${ }^{22}$ The qualitative evidence for interpersonal violence in the non-Western world before modern times is equally patchy. We know about banditry, for example, in colonial societies such as India and Indonesia in the eighteenth and nineteenth centuries. ${ }^{23}$ In many colonial societies the factor of race or the institution of slavery contributed to the incidence of homicide. ${ }^{24}$ Finally, indigenous beliefs played a facilitating role, as in the medicine murders in Lesotho, 1895-1969, and the man-leopard murders in Nigeria and Ghana, 1945-48. ${ }^{25}$ That is about all. The need for a large-scale research project, examining homicide in the long-term perspective in a few selected nonWestern countries, is as great as ever.

Two indirect routes are available for making at least assumptions about interpersonal violence and homicide in non-Western societies in the distant past. One revolves around honour. The central role of traditional male honour in European violence since the middle ages will be a familiar theme for most readers. We also know that honour and violence were similarly linked in many non-European societies. Hence, if there is evidence for a substantial preoccupation with traditional honour in these societies in the distant past, we may assume correspondingly high levels of interpersonal violence. And the evidence abounds. Traditional male honor was valued throughout the history of Latin America and in many parts of Asia, such as ancient Japan and Indonesia from pre-colonial times. ${ }^{26}$ For Africa, there is the

20 Johnson et al. (2012).

21 Buoye (2000, pp. 1-16).

22 This conclusion can also be drawn from Meijer (1991). In the pre-colonial Ashanti kingdom, on the other hand, payment of blood money and reconciliation usually followed on a homicide: Hynd at $4^{\text {th }}$ workshop.

23 Srivastava and Bloembergen at $2^{\text {nd }}$ workshop.

24 Cf. various publications referred to in Johnson et al. (2012); Kolsky (2010).

25 Murray, Sanders (2005); Pratten (2007). Murray and Pratten presented an update of their conclusions at the $2^{\text {nd }}$ workshop. Stacey Hynd provided additional details at the $4^{\text {th }}$ workshop.

26 On Latin America, see Johnson, Lipsett-Rivera (1998) and various contributions to Johnson et al. (2013). For Japan, see Ikegami (1995); and for Indonesia see Cribb at $2^{\text {nd }}$ workshop. 
pioneering work of John Iliffe ${ }^{27}$ drawing on some forty years of research. Based, among others, on literary sources going back to the middle ages, he documents the importance of warrior-like notions of male honour for the horse-riding elites of the sub-Saharan savannas, the Ethiopian highlands and many other regions. We can conclude that traditional male honor was cherished by nearly all social classes throughout the African continent in precolonial times, in states as well as stateless societies. In addition, Iliffe discusses the survival of this ethos in Africa's present.

The second indirect route takes the world's most recent homicide rates as its point of departure. We do know that in most of Latin America and Africa and many parts of Asia the modern rates are particularly high, which makes it unlikely (unless the rates were even much more elevated in the distant past) that a long-term decline in any way similar to that in Europe has taken place. Theoretically this presents no great problem. The countries in question usually also lack a history of centuries-long state formation coupled with processes of pacification and economic integration. Taken together, the two indirect routes suggest a very crude hypothesis: Homicide in the non-Western world has always been relatively high from the distant past until today. Of course this hypothesis excludes all possible fluctuations in the past that might or might not be due to temporary state building and state failure. It is wellknown, to take a recent example, that the breakdown of the Soviet Union led to an upsurge of homicide rates. Thus, the crude hypothesis does not take us very far. Our ignorance about global homicide over the long term precludes an answer to the question whether Elias' theory might be creatively employed to account for it or, conversely, might be unhelpful to explain what remains to be found.

With respect to the European history of homicide and violence, finally, Gregory Hanlon recently contributed to the theoretical debate in a lengthy review article. The main argument, as far as I can grasp it, is that nearly all historians have failed to take adequate account of the biological factors in human behaviour. Since the brunt of his attack is reserved for those historians, among whom myself, who use Elias' theory, he is apparently unaware of what Elias and scholars inspired by him write about the biological basis of social behaviour. ${ }^{28}$ Pinning the label 'cultural' on a number of studies, he believes he can discredit these by proclaiming them representative of a 'world view of 1970'. ${ }^{29}$ I will resist the temptation to call Hanlon's essay representative of the age of Lombroso. He accepts the evidence for the long-term decline of homicide, referring to it several times without denying that it happened, yet makes the implicit claim that all violence is a function of testosterone and traits that we have inherited from our ancestral primates. Indeed, it is not testosterone alone, because he additionally claims that infanticide has been much more frequent than most historians have assumed and hence women are equally murderous as men: "In fact, the decision of a mother to destroy the newborn or the foetus is something that has changed little over time. Today, women abort between twelve and twentyfive per cent of their pregnancies." ${ }^{30}$ This equation of abortion and murder will most certainly be pleasing to American pro-life activists, who will, however, shy away

27 Iliffe (2005).

28 See, for example, Elias (1991); Shilling (1993).

29 Compare his review of Spierenburg (2012) in the Journal of Interdisciplinary History 44, 3 (2014, pp. 379-381).

30 Hanlon (2013, p. 374). 
from a biological explanation. Hanlon closes with the incomprehensible statement that we still know little about homicide in various periods, the profile of victims and killers or what is to be found in court records.

Proceeding to an update for the state of the art regarding organized murder, my main question is to what extent the relative neglect of the period before about 1870 has been made undone. ${ }^{31}$ A sociological study by Jacques Sémelin, not referred to in the earlier state of the art, continues the traditional chronology. He focuses on genocide and the underlying drive, as he sees it, for purification through destruction, but he views all this as a special type of the encompassing category of massacre. Considering purification through destruction as characteristic for the twentieth century, Sémelin selects his cases accordingly. He concludes with seven major questions, each subdivided, that deserve attention in future research into massacres. ${ }^{32}$ For his part, Christian Gerlach ${ }^{33}$ introduces still another concept, that of "extremely violent societies." He simply observes these societies almost anywhere in the twentieth century. The implicit claim that this century was the most violent in history is an a priori, not based on comparative research. ${ }^{34}$

In Johnson et al..$^{35}$ we acknowledged that one general study of genocide by Kiernan $^{36}$ did devote more than minimal attention to earlier periods of history. However, Kiernan is mainly concerned with identifying a few factors that, according to him, operate in every genocide, instead of identifying long-term trends. Even for him 1900 constitutes a definite dividing line, since the last of his three parts, entitled twentieth-century genocides, covers half of the book. In the 2010s attention for mass killing is definitely on the increase. A six-volume set edited by A. Dirk Moses ${ }^{37}$ is no new study but an anthology. One volume is entitled genocide before modernity and another, on colonial and imperial genocides, partly covers earlier periods. Thus, the imbalance in favour of the last 150 years is maintained, but the editor has gathered a lot of data from earlier periods that spare other scholars a laborious search. Christopher Powell ${ }^{38}$ presents a sociological study of six selected - hence no pretension of completeness - cases of genocide. The cases are relatively recent, except for the destruction of Catharism in Languedoc between 1209 and 1321. Powell offers a complex theory, stating that processes of civilization are always accompanied by its opposite, barbarization. In my perhaps too simplified version, the theory implies that, wherever violence is monopolized, it must be periodically unleashed.

A collection edited by Philip Dwyer and Lyndall Ryan follows Sémelin in considering massacre a broader category encompassing genocide. According to the editors, "genocide cannot occur without massacre, but massacres do occur without

31 An emphasis on modern times is also apparent in review articles such as Mazower (2002); Bloxham (2008); Bartov (2008).

32 Sémelin (2007). The original French version was unavailable to me.

33 Gerlach (2010).

34 Compare the review by Andrew Finstuen in American Historical Review 2012, 1.

35 Johnson et al. (2012).

36 Kiernan (2007).

37 Moses (2010).

38 Powell (2011). 
genocidal intent". ${ }^{39}$ Ten out of twenty contributions to this collection concern the last 150 years and nine the rest of history (one is general). A collection of essays by Adam Jones ${ }^{40}$ echoes several times Lemkin's statement that genocide is of all times, but Jones nevertheless focuses almost exclusively on the modern period. Finally, the book by Steven Pinker has already raised considerable debate. ${ }^{41}$ He uses Elias, with a restricted understanding of the latter's theory though. Thus, Pinker's discussion of the 'rights revolutions' could easily be integrated into Elias' theory of decreasing power differentials. Up to now, Pinker is the only author who explicitly argues that humans, at least in the Western world, have become less violent over the centuries. Note that he means overall violence, including every conceivable military activity, civil wars and revolutions. His figures have to be broken down in order to establish whether they show a downward trend over the ages for organized murder alone. Moreover, several scholars express doubts about his statistics. Hanlon's evaluation is notoriously split, because he has to praise Pinker for his attention to biology and psychology, yet dismisses all his statistics ${ }^{42}$. This criticism provides an obvious caveat. Yet, in view of all recent studies together, I venture the statement that there is an emerging answer that appears to confirm Eric Johnson's and my original hunch that it is far from certain that organized murder belongs especially to the last 150 years.

Nevertheless, some serious problems of methodology remain. We may start with that of counting and estimating, just raised. A hunch is not yet an exact number. Can we count organized murder at all ? Will we ever be able to arrive at estimates that are more than just guesses? Doubts about reaching reliable estimates were expressed also during the series of workshops that I organized. David Robinson, for example, discussing the violence with which the first two Ming emperors established their dynasty, finds that several chroniclers mention a suspiciously round number like 10,000 killed. On other occasions, the numbers have earned their standard status in historical scholarship merely from repetition. Yet, he believes that careful research may yield better estimates in the future..$^{43}$ Perhaps the most reliable estimate, on the other hand, concerning an episode of organized murder well before the last 150 years, is that of the numbers killed in the Vendée in 1793-1794. Based on population counts in 1792 and 1802, Reynald Secher establishes that in the latter year 14.38\% of the inhabitants had 'disappeared' - a suggestively modern term. Further, based on a few local specifications, we can fix the percentage of combatants among those who perished at well under ten. ${ }^{44}$ There is no reason to assume a surplus of natural deaths over births during the ten years in question. Hence, $10 \%$ of the non-combatant population murdered is a moderate estimate.

A minor problem lies in the fact that past chroniclers tend to take the social status of victims into account. This has been pointed out for, among other cases, the religious upheavals in sixteenth-century France and massacres in medieval Russia. The chroniclers were especially outraged, or just astonished, at the killing of persons

\footnotetext{
39 Dwyer, Ryan (2012, p.xiii).

40 Jones (2013).

41 Here I am referring to the Dutch translation Pinker (2011), which is the one available to me.

42 Hanlon (2013).

43 Robinson at third workshop.

44 Secher (1986, pp. 253-260).
} 
of 'quality'. In medieval Russia they considered it a massive loss when ten knights were murdered, which equalled, say, a thousand peasants. ${ }^{45}$ Hence, when the sources just use words like "many", we must be sure about what kind of victims they speak. In some cases, finally, an entire event may be doubt. Thus, many scholars dismiss as a fabrication the alleged murder of over sixty thousand Christians by Jews after the Persian conquest of Jerusalem in 614. The story is strange indeed, especially the detail that the Jews first bought the Christians, held captive by the Persians. Yet, Elliott Horowitz, who carefully unravels facts about Jewish violence from antiSemitic myth-making throughout history, refrains from a pronouncement about whether or not the 614 event has occurred at all. ${ }^{46}$

As in the Vendean case, demography sometimes can help us out. Population estimates are usually more reliable than murder estimates. However, organized murder often coincides with starvation and disease, while we have no idea what percentage died a violent death. This just happens to apply hardly to the Vendée. Its inhabitants and the Revolutionary soldiers and their ancestors had been, in McNeill's terms, in the same disease pool for ages. As is well-known, the quick collapse of the Aztec and Inca empires was due, in large part, to the inhabitants' lack of antibodies against the diseases that the conquerors brought with them ${ }^{47}$ It would be ridiculous to confuse death from smallpox with deliberate killing. ${ }^{48}$ In a similar vein, we know that the population of Congo decreased from twenty million in 1880 to ten million in 1920, but again most of the loss was due to the import of illnesses. ${ }^{49}$ Only a small part of the ten million disappearances was due to outright murder, and although sufficient cases are documented, the exact number once more is a guess.

In view of all uncertainties, it is understandable that several scholars have dismissed earlier efforts at collecting figures for organized murder over long periods of time, in particular those by Rudolph J. Rummel (including figures for deaths in wars).$^{50}$ Gerlach, for example, calls all of Rummel's books "sensationalist", considering their content as "greatly inflated numbers". ${ }^{51}$ Nevertheless, Powell relies on these very numbers when discussing the persecution of the Cathars. Pinker, too, partly relies on Rummel, but to a greater extent on the work of Matthew White. ${ }^{52}$ In each case, White takes the mean figure of all available estimates to be found in the literature, but in view of the above considerations, it is far from certain that this exercise increases reliability. Yet, the question remains whether anyone can do better than Pinker and White.

Pinker does provide a definite improvement over most quantitative reflections: he relates the absolute numbers, referring to wars and mass murders, to population

45 Carroll and Muravyeva at first workshop. On religious violence in $16^{\text {th }}$-century France, see the set of articles in Past \& Present, 214, supplement 7 (2012).

46 Horowitz (2006, pp. 229-247).

47 McNeill (1977, pp. 199-218). See also Livi Bacci (2007, pp. 43-49).

48 Or, for that matter, to blame the Mongols who besieged Caffa for the Black Death throughout Europe.

49 Hochchild (1998, pp. 226-234).

50 Rummel (1997, pp. 14-28), despite the "since 1900" in the title, additionally presents estimates going back to the 30th century BC. See also Rummel (2008).

51 Gerlach (2010, p. 257).

52 White (2012). See Pinker, 2011, p. 208 (calling Rummel's and White's calculations about equally careful) and pp. 473-474 (implying that White is more reliable than Rummel). 
figures. ${ }^{53}$ What struck me most when I first began to read about organized murder was how often, when various cases were compared at all, this was done in terms of absolute numbers alone. Coming from the study of homicide, I considered it selfevident that the raw numbers must be turned into a rate or ratio somehow. Take an example from Antiquity that is usually subsumed under the heading of genocide. In 416 BC the Athenians, hard pressed by the Spartans and wishing to deter other allies, decided on an exemplary punishment for the defection of the small island of Melos. They killed all adult men that they had taken as prisoners of war, numbering 500, and sold the women and children into slavery (estimate based on the 500 Athenian families that replaced them).$^{54}$ Knowing about the millions of victims made by Hitler and Stalin, should we consider the Athenians much less harsh? Imagine them in possession of a device for looking into the future. Seeing that a political leader orders the extermination of 6 million people, they exclaim "now, that's exemplary punishment; let's do it too". Classical Greece, including Epiros, Macedonia and all Egean islands, had just over 3 million inhabitants and another 800,000 (including a majority of non-Greek slaves) lived on Sicily and in Southern Italy. ${ }^{55}$ If the Athenians had wanted to emulate the Holocaust, obviously, they would have had to reach far beyond their known world. This thought-exercise should be enough to convince readers that organized murder ought to be related to population figures.

That conclusion, however, is just the beginning of a new problem. What should be the referent? With episodes of organized murder in a colony, for example, it might seem obvious that the entire number of native inhabitants is the reference population. But when we take the episode as symptomatic of murderous intentions in the mother country, shouldn't we also take its population into account? And what about an episode taking place over centuries, such as the extermination of native Americans, that most historians consider as one genocide? Conversely, the kingdom of Ahom in present-day Assam was plagued throughout its existence (1228-1826) by head-hunting tribes from the surrounding hills. ${ }^{56}$ In other cases there is no consensus about what belongs to what and which instances of killing we should take together. Thus, Kiernan devotes a few lines to various outbreaks of mass killing in the Ottoman Empire in the second half of the nineteenth century, conveniently considering them as preludes to the Armenian case and hence belonging to a twentieth-century phenomenon. By contrast, Ussama Makdisi analyzes the mutual massacres of Druzes and Maronites in Lebanon in 1860 as a consequence of administrative and social changes during the preceding decades. ${ }^{57}$

When we return to the comparison of Athenians and Nazis, one procedure might be to consider their respective victims as percentages of the targeted population.

53 It is not entirely clear to which population figures. According to p.283, Pinker has adapted White's numbers to the world population at the middle year of the episode concerned. Rummel (2008) provides annual percentages from the total population for individual "democides" of the $20^{\text {th }}$ century, but the main focus is on absolute numbers. Table 2.2 in Rummel (1997) provides percentages per century, presumably from the estimated world population. For an example of meticulous calculations in a global context, see Parker (2013). He, however, does not provide any murder figures (At p. 510 he presents a graph for cases of rebellion and banditry in Ming China but not for numbers of victims).

54 Bosworth in Dwyer, Ryan (2012, p. 22).

55 Corvisier, Suder (2000, pp. 34 \& 44) and information from Paul Schulten.

56 Handique at $2^{\text {nd }}$ workshop.

57 Makdisi (2000); Kiernan (2007, p. 397). Kiernan does not refer to Makdisi. 
How many of those they were after did they kill? Lucy Dawidowitz establishes this for the Jews exterminated in the Final Solution. She puts the estimated number of Jews who perished, from Germany and each occupied country, next to the estimated pre-final-solution Jewish population. The overall estimate of victims comes at $67 \% .{ }^{58}$ If we take the Athenians as targeting all Melians, their killing of adult men only makes them less murderous than the Nazis. However, if we take into account that in Ancient thought the women and children did not really matter, or conversely, that selling a person into slavery is almost as bad, the Athenians come near to $100 \%$. Of course this involves a rather wild comparison of two cases selected for the sake of the argument. Doing a global study over the long term, we should perhaps consider entire continents per century. For each century we could relate the number of people killed in episodes of organized murder to the population of the continent in question, averaged during that century. Of course, the further we go back into history, the larger the likelihood of a dark number of missed episodes.

Fortunately, we can do more than just counting. As with homicide, the history of organized murder may exhibit trends over time in the form of changing characteristics. For the moment I am distinguishing two characteristics and their corresponding research questions: concealment and legitimation. The first can be easily plotted on an axis with the pole of total concealment from any third party at one end and letting all the world know at the other. Of course the gas chambers of the Holocaust are near the first pole. Frankly admitting organized murder, on the other hand, or even pride in it, have been attested since Antiquity. Caesar, for example, included his orders to kill non-combatants, many of them women and children, as something self-evident in his De Bello Gallico. ${ }^{59}$ Medieval chronicles, remaining imprecise about concrete events, attest abundantly to genocidal thought. ${ }^{60}$ Chingis Khan's warriors were required to send him bags with the ears of the inhabitants of conquered towns as proof that these had been slaughtered. In a similar vein, between 100,000 and 200,000 Korean noses were reportedly sent to Japan at the end of the sixteenth century. ${ }^{61}$ As a final example let me mention Haiti, 1802-1804, where white-on-black killing was followed by the rare case of a black-on-white genocide. Both racial groups practiced their violence openly in market squares, which Philippe Girard explicitly contrasts with the Holocaust. ${ }^{62}$

In view of all this, the hypothesis of a long-term trend from advertizing to concealing organized murder does not seem far-fetched. In the words of Dwyer and Ryan: "The tendency to cover up a massacre or mass killing is a relatively recent phenomenon". ${ }^{63}$ For Australia, they date it from the turn of the eighteenth and nineteenth centuries. As a further exercise, the factor of concealment can be analytically subdivided into hiding the events from onlookers at the spot and from the home population. Srebrenica

58 Dawidowitz (1987, p. 480, appendix B). The real percentage must be a little higher because the prefinal solution figures for Russia and Ukraine, which were not occupied entirely, refer to all of the territory. The definitive count of the absolute numbers of victims is in Benz (1991), to which I am referring below.

59 Isaac in Moses (2010, vol.II, pp. 141-50); Bellemore (2012, pp. 38-49).

60 Scales in Moses (2010, vol.II, pp. 173-92); Scales in Dwyer, Ryan at $4^{\text {th }}$ workshop.

61 Saunders in Moses (2010, vol.II, pp. 193-220); McCormack in idem (pp. 358-360).

62 Girard in Moses (2010, vol.III, pp. 57-80). Compare Robins (2005) who ascribes genocidal intent to native insurgents in the Americas.

63 Dwyer, Ryan (2012, p. xix). 
1995, where the perpetrators led their prospective victims away from UN troops, is an example of the first. ${ }^{64}$ Of course, this possibility does not exist in cases, such as Melos, where everyone at the spot was either perpetrator or victim. The possibility of concealment from the home population applies in particular to organized murder in a colony. As a special case we may consider the behaviour of the perpetrators' biological or spiritual heirs. Most neo-Nazis, for example, claim that the size of the Holocaust has been exaggerated, while, alternatively, they could have praised Hitler for it. The present Turkish government denies that Ottomans committed a genocide against Armenians and punishes those who say otherwise.

In France, by contrast, you can be sentenced for denying the Armenian genocide ${ }^{65}$ The hypothesis of increasing concealment obviously refers to the perpetrators and their heirs. The counter-tendency of revealing organized murder stems from those who want to denounce the perpetrators. This tendency may be even more recent. Thus, Totten and Parsons contrast the killing of some two to three hundred thousand Hutus, mainly by Tutsis, in Burundi in 1972 with the events in Rwanda twenty-two years later: "Unlike what happened in Rwanda, the carnage attracted only minimal attention from the media". ${ }^{66}$ Elias and Dunning were among the first to suggest that it is not genocide as such which is modern, but the increasing revulsion against it. ${ }^{67}$ This revulsion arose in the Western world after the Second World War, when the enormity of the Holocaust came to light. Presently, organized murder tends to get denounced wherever it occurs in the world.

It is much harder to answer the second research question - in what way perpetrators of organized murder legitimize their actions - in terms of a long-term trend from a to b. Legitimations can be manifold. During China's Great Leap Forward, for example, party officials felt connected in a comradeship of violence, in which beating a worker, sometimes to death, was justified by his laziness. ${ }^{68}$ Members of the SS and their fellows who participated in the Holocaust, saw themselves as honourable defenders of their country against a conspiracy of world Jewry ${ }^{69}$ Going back in time, we find a black leader in Haiti justifying the murder of whites as necessary to prevent a return to slavery. A decade earlier the slaveholders' compatriot Robespierre, speaking about the Vendéens, put it like this: "We have to extinguish the internal enemies of the Republic or perish with them".$^{70}$ Again some three to four decades earlier the Qianlong emperor justified the extermination of the Zhungars with the argument that the barbarians had become increasingly rebellious and that, if he failed to defend the empire's borders, he could not face his father and grandfather in the hereafter. ${ }^{71}$ Finally, a change in medieval Russia, where chroniclers routinely wrote about the

64 [http://www.niod.knaw.nl/en/srebrenica-report] (4-4-2014).

65 Personally, I find laws that condemn the denial of the Holocaust or any other genocide an outrage against the principle that truth in scholarship should be established through free discussion, not decreed legally.

66 Totten, Parsons (2009, p. 323).

67 Dunning (2008, pp. 240-243) discussing the theoretical contributions of Elias and himself.

68 Dikötter (2011, p. 350).

69 Gleichmann, Kühne (2004, p. 46).

$70 \quad$ "Il faut étouffer les ennemis intérieurs de la République ou périr avec elle." Quoted in Secher (1986, p. 296).

71 Perdue in Moses (2010, vol.II, p. 249). 
mass killing of non-combatants or prisoners of war, may be relevant in this respect. Chroniclers of the tenth and eleventh centuries reported this without emotion as a fact of life, whereas their twelfth-century successors condemned it, always adding that it was an exceptional case. ${ }^{72}$ It is not clear yet whether this involved a change at the level of legitimation or in real frequency. In the field of the legitimation of organized murder, to conclude, more systematic research is needed.

Let me end with a comparative exercise that involves both the pure counting of victims and establishing characteristics over time - and that in the European context. I examine three episodes of organized murder, all containing a heavy dose of antiSemitism, that respectively took place in 1096, 1348-1350 and 1941-1945. Since I am concerned with trends over time, I compare both the first and second episode with the third. I consider the basic facts of the Holocaust as part of general knowledge that needs no reference. My source for the first episode is the work of Robert Chazan and for the second that of Frantisek Graus. ${ }^{73}$

The 1096 episode took place on the eve of the first crusade. Fanatic preachers, considering Jews equally infidel as Muslims, pointed out that the troops on their way to the Holy Land would conveniently pass them by. Their call led to an orchestrated murder of Jews. Contrary to what earlier authors assumed, this episode was not noted for the numbers killed. ${ }^{74}$ In fact, the coalition of crusaders and citizens attacked, not dozens, but three Jewish communities, those of Worms, Mainz and Cologne. These were almost completely annihilated though, despite attempts at protection by the respective bishops and a few sympathetic citizens. The year 1096 was notorious, in comparison with the Holocaust, for the way in which the murders were carried out. In 1096 there was quite open slaughter in the streets and, after a chase, in the victims' own homes. The attackers pierced them with arrows and spears. Some Jews reacted with - ultimately unsuccessful - counter-violence, others with suicide, still others with mutual killing to prevent themselves from falling into the hands of the impure uncircumcized. One young mother quietly awaited the crusaders amidst the corpses of her four children whom she had just stabbed to death. For the Jewish survivors this was an example of sincere martyrdom, for the crusaders a sign of Jewish perfidy and one more justification for their own actions.

There is less information on the circumstances in which the persons held responsible for the Black Death were killed, so let me compare this episode with the Holocaust on the issue of numbers. We can best denote the victims of 13481350 as alleged poisoners of wells, because next to Jews they included a minority of Christians and heretics accused of this crime, while Catalans were the main targets in Sicily. ${ }^{75}$ This increases their similarity to the group of victims in 1941-1945, who included a number of Romas and gays. For brevity's sake I denote those killed in the fourteenth and the twentieth century, respectively, as VWPA (victims of the wellpoisoning accusation) and HV (Holocaust victims). The geographic scope of the two episodes is also relatively similar. The murder of VWPA began in Southern France, reaching from there into Catalonia and Savoie and consecutively to the Holy Roman

\footnotetext{
Karachinsky at 3rd workshop.

73 Chazan (1996); Graus (1987).

74 Kiernan (2007, pp. 64-65) echoes the earlier authors, not Chazan.

75 Catalans in Cohn (2007, p. 8). While Cohn is concerned more with motives than numbers, Graus does not include Sicily in his figures.
} 
Empire as far as Königsberg; there were scattered pogroms in the Netherlands and Poland. Hence both cases of organized murder took place in large parts of Europe within a few years. However, whereas the Holocaust had been completely organized from above, during the Black Death it was a combination of spontaneous killings by angry crowds and quasi-legal executions, usually by burning. The latter were sometimes instigated by city councils, despite the Pope's disapproval.

Perhaps my quantitative comparison is open to the same criticism as mentioned above, but it is worth a try, also in view of the meticulousness of Graus' study, relatively unknown among Anglo-Saxon scholars. In the case of the VWPA we are faced with the additional methodological problem that, for the population figures, we have to choose between pre-plague and post-plague, which makes a huge difference. Since the accusation obviously surfaced when the plague had already struck Europe, it is fair to take the post-plague population as the referent (in the demographic literature this usually means the estimate for 1400). In any case, the infection struck both perpetrators and victims, as well as non-participants. Moreover, in view of Germany's central role in both episodes - in 1348-1350 as the heartland of the murders and in 1941-1945 as main organizer - I want to calculate separate figures for the whole of Europe and for Germany alone. Europe at the time of the Holocaust stands for all parts under Nazi influence, while Europe at the time of the Black Death stands for all parts except those hardly affected by the disease (the Balkans and Southern Russia). This means that I am adding a few assumptions to the demographic estimates. The result can be considered as a preliminary exercise. My calculations are specified in the footnote to this sentence, so that others can improve on them. ${ }^{76}$

The results of my calculations from the demographic literature are the following: 64 million inhabitants for Europe struck by the Black Death; 8 million for Germany at that time; 400 million for Europe under Nazi influence; 70 million for Germany at the beginning of the Second World War. The number of VWPA, admittedly, is an extrapolation. ${ }^{77}$ My estimates, based on Graus, come at a total of 48,800 VWPA, of

76 Livi Bacci (2000, p. 6) has 600 million for Europe from Atlantic to Ural in 1950, whereas McEvedy \& Jones (1978, p. 18) have, for the same area, 530 million pre-World War II and 515 million postWorld War II. Livi Bacci (2007, p. 26) has 393 million in 1950 for Europe without the territory of the USSR. In view of these divergent figures, I put the population of Europe from Atlantic to Ural during World War II at 550 million. From this we have to subtract the population (based on McEvedy, Jones) of the British Isles (53.5 million), Iberia (35 million) and an estimated 61.5 million for Switzerland and the non-occupied parts of Russia and Scandinavia. Hence, the population of Europe under Nazi influence during WW II comes at 400 million.

Livi Bacci (2000, p. 6) has 75 million for Europe from Atlantic to Ural in 1400, whereas McEvedy \& Jones (1978, p.18) have, for the same area, 60 million in 1400. Livi Bacci (2007, p. 26) has 52 million in 1400 for Europe without the territory of the former USSR. I put the post-plague population of Europe at 70 million and, based on McEvedy \& Jones, I subtract 6 million for the Balkans and Southern Russia. Hence, the plague-stricken population of Europe comes at 64 million.

Germany during the well-poisoning scare extends from the Alps to Königsberg. McEvedy \& Jones (1978, pp. 69-71) have 6.5 million in 1400 for Germany within its present borders, and 12.5 million for the whole of the Holy Roman Empire (including its Italian parts) in 1400. I put Germany's postplague population at 8 million.

[http://www.tacitus.nu/historical-atlas/population/germany.htm] (8 April 2014) indicates a population $\mathrm{n} 1939$ of 69.5 million for the Reich (within the borders of 1937). This refers to the same area considered as Germany in Benz (ed.) (1991). I round this off to 70 million.

77 Graus (1987, p. 249) lists exact numbers, which he considers very probable, of Jews killed for eight German-speaking towns. The total number of Jewish victims in these towns comes at 5,848. Allow- 
which 38,800 in Germany. Benz fixes the total number of Jews killed in the Holocaust between a minimum of 5.29 million and a maximum of just over 6 million. ${ }^{78}$ Allowing for the non-Jewish victims, I am sticking to the traditional figure of six million HV rather than mediating these two numbers. He considers 165,000 German Jewish victims a realistic estimate. ${ }^{79}$ Again allowing for the others, I fix the total number of German HV at 170,000. Hence, if we consider Germany alone, the well-poisoning scare was twice as bad $(0.485 \%$ of its total population) as the Holocaust $(0.243 \%$ of its total population). For Europe this is the reverse. Whereas the number of VWPA amounts to a "mere" $0.076 \%$ of the population, that of HV comes at $1.5 \%$. However, several considerations have to be taken into account with respect to the estimate of VWPA in Europe. Graus' research was most exhaustive for Germany. Moreover, he notes that very few Jews - the main target group - lived in France after an expulsion twenty-fine years earlier. This also applies to England after the expulsion of 1290. Finally, as the case of the Sicilian Catalans suggests, there may have been other scapegoats in various places. For the moment, let us assume that the Holocaust and the well-poisoning scare were in the same category of magnitude.

\title{
CONCLUSION
}

A superficial examination of the historical literature on homicide and organized murder yields two diametrically opposed conclusions, designating the last 150 years, respectively, as the most peaceful and the most violent era ever. In fact, both of these preliminary conclusions are based on incomplete research. The research into the long-term history of homicide has been largely restricted to Europe and North America. There is no sign, unfortunately, that this situation will be remedied soon. With respect to organized murder, on the other hand, enough work has been done recently to cast doubt on the claim that it was especially characteristic for the last 150 years or so. Although estimating its quantitative dimensions relative to population figures over time remains a hazardous enterprise, it appears possible to do so with greater precision in the future. Another promising research question lies in identifying, globally, long-term changes in the characteristics of organized murder.

\author{
Pieter Spierenburg \\ Professor Emeritus \\ Erasmus Universiteit Rotterdam \\ Binnenkant 27, \\ NL - 1011 BJ Amsterdam \\ spierenburg@law.eur.nl
}

ing for a few Christians and heretics accused of well-poisoning, we can round this off to 6,000 which is 750 per town. The eight towns were all big. Graus lists a total of 44 big towns (including a few regions) in Germany where Jews were killed. With 750 victims per town, the total comes at 33,000. Graus lists another 58 small towns, whose average number of victims I put at 100 . This puts the total of VWPA in Germany at 38,800. Graus does not specify all non-German areas where Jews were killed. He mentions seven regions and big towns and fourteen small towns in France and five towns in Catalonia. I put the number of non-German VWPA arbitrarily at 10,000.

78 Benz (ed.) (1991, p. 17).

79 Ibidem, p. 15 (p. 64 reveals that this is within the borders of 1937). 


\section{REFERENCES}

Bartov, O., Eastern Europe as the site of genocide, Journal of Modern History, 2008, 80, 3, pp. 557-593.

Benz, W. (ed.), Dimension des Völkermords. Die Zahl der jüdischen Opfer des Nationalsozialismus, Munich, Oldenbourg, 1991.

Bloxham, D., Modernity and genocide, European History Quarterly, 2008, 38, pp. 294-311.

Buoye, T. M., Manslaughter, markets, and moral economy. Violent disputes over property rights in eighteenth-century China, Cambridge, CUP, 2000.

Carmichael, C., Genocide before the Holocaust, New Haven, Yale University Press, 2009.

Chazan, R., In the year 1096. The first crusade and the Jews, Philadelphia, Jewish Publication Society, 1996.

Cohn, S. K., The Black Death and the burning of Jews, Past \& Present, 2007, 196, pp. 3-36.

Corvisier, J.-N., Suder, W., La population de l'Antiquité classique, Paris, PUF, 2000.

Dawidowitz, L. S., The war against the Jews, 1933-1945 (5th ed.), London, Penguin, 1987.

Dikötter, F., Mao's massamoord. De geschiedenis van China's meest vernietigende catastrofe, 1958-1962, Houten, Spectrum, 2011.

Dodds Pennock, C., Mass murder or religious homicide? Rethinking human sacrifice and interpersonal violence in Aztec society, Historical Social Research/ Historische Sozialforschung, 2012, 37, 3, pp. 276-302.

Dunning, E., Violence and violence-control in long-term perspective: 'Testing' Elias in relation to war, genocide, crime, punishment and sport, in Body-Gendrot, S., Spierenburg, P. (Eds), Violence in Europe. Historical and contemporary perspectives, New York, Springer, 2008, pp. 227-249.

Dwyer, P. G., Ryan, L. (Eds), Theatres of violence: Massacre, mass killing and atrocity throughout history, New York, Berghahn Books, 2012.

Elias, N., On human beings and their emotions: A process-sociological essa', in Featherstone, M. et al. (Eds), The body. Social process and cultural theory, London, Sage, 1991, pp. 103125.

Few, M., Medical humanitarianism and smallpox inoculation in $18^{\text {th }}$-century Guatemala, Historical Social Research/ Historische Sozialforschung, 2012, 37, 3, pp. 303-317.

Gabbert, W., The longue durée of Colonial violence in Latin America, Historical Social Research/ Historische Sozialforschung, 2012, 37, 3, pp. 254-275.

Gerlach, C., Extremely violent societies : Mass-violence in the 20th-century world, Cambridge, CUP, 2010.

Gleichmann, P. R., Kühne, T. (Eds), Massenhaftes Töten. Kriege und Genozide im 20. Jahrhundert, Essen, Klartext Verlag, 2004.

Graus, F., Pest, Geissler, Judenmorde. Das 14. Jahrhundert als Krisenzeit, Göttingen, Vandenhoeck \& Ruprecht, 1987.

Hanlon, G., Review article: The decline of violence in the West: From cultural to post-cultural history, English Historical Review, 2013, 128, 531, pp. 367-400.

Hochchild, A., King Leopold's ghost. A story of greed, terror and heroism in Colonial Africa, Boston, Houghton Mifflin Company, 1998.

Horowitz, E., Reckless rites: Purim and the legacy of Jewish violence, Princeton, Princeton University Press, 2006.

Ikegami, E., The taming of the samurai. Honorific individualism and the making of modern Japan, Cambridge MA., Harvard University Press, 1995.

Iliffe, J., Honour in African History, Cambridge, CUP, 2005. 
Johnson, E. A. et al., Murder and Mass Murder in Pre-Modern Latin America: From PreColonial Aztec Sacrifices to the End of Colonial Rule, an Introductory Comparison with European Societies, Historical Social Research/ Historische Sozialforschung, 2012, 37, 3, pp. 233-253.

Johnson, E. A. et al. (Eds), Murder and Violence in Modern Latin America, Chichester, Wiley (Bulletin of Latin American Research Book Series), 2013.

Johnson, L. L., Lipsett-Rivera, S. (Eds), The faces of honor: Sex, shame and violence in Colonial Latin America, Albuquerque, University of New Mexico Press, 1998.

Jones, A., The scourge of genocide: Essays and reflections, London, Routledge, 2013.

Kiernan, B., Blood and soil: A world history of genocide and extermination from Sparta to Darfur, New Haven, Yale University Press, 2007.

Kolsky, E., Colonial justice in British India, Cambridge, CUP, 2010.

Lemkin, R., Axis rule in occupied Europe: Laws of occupation, analysis of government, proposals for redress, New York, Howard Fertig, 1973[1944].

Livi Bacci, M., The population of Europe. A history, Oxford, Blackwell, 2000.

Livi Bacci, M., A concise history of world population (4 ${ }^{\text {th }}$ edition), Oxford, Blackwell, 2007.

McEvedy, C., Jones, R., Atlas of world population history, London, Allen Lane, 1978.

McNeill, W. H., Plagues and peoples, Oxford, Blackwell, 1977.

Makdisi, U., The culture of sectarianism: Community, history and violence in $19^{\text {th }}$-century Ottoman Lebanon, Berkeley, University of California Press, 2000.

Mazower, M., Violence and the state in the twentieth century, American Historical Review, 2002, 107, 4, pp. 1158-1178.

Meijer, M. J., Murder and adultery in late Imperial China: A study of law and morality, Leiden, Brill, 1991.

Melber, H. (ed.), Revisiting the heart of darkness: Explorations into genocide and other forms of mass violence, Uppsala, Dag Hammarskjöld Centre, 2008.

Moses, A. D. (ed.), Genocide: Critical concepts in historical studies, 6 vols., London, Routledge, 2010.

Murray, C., Sanders, P.B., Medicine murder in colonial Lesotho: The anatomy of a moral crisis, Edinburgh, Edinburgh University Press, 2005.

Parker, G., Global crisis. War, climate change and catastrophe in the $17^{\text {th }}$ century, New Haven, Yale University Press, 2013.

Pinker S., Ons betere ik: Waarom de mens steeds minder geweld gebruikt, Amsterdam, Contact, 2011.

Powell, C., Barbaric civilization : A critical sociology of genocide, Montreal, McGill-Queen's University Press, 2011.

Pratten, D., The man-leopard murders: History and society in Colonial Nigeria, Edinburgh, Edinburgh University Press, 2007.

Reybrouck, D. van, Congo: Een geschiedenis, Amsterdam, De Bezige Bij, 2010.

Robins, N. A., Native insurgencies and the genocidal impulse in the Americas, Bloomington, Indiana University Press, 2005.

Rummel, R. J., Statistics of democide: Genocide and mass murder since 1900, Münster, Lit Verlag, 1997.

Rummel, R. J., Death by government (with a foreword by Irving Louis Horowitz), (Sixth edition), New Brunswick, Transaction Publishers, 2008.

Secher, R., Le génocide franco-français : La Vendée-Vengé, Paris, PUF, 1986.

Sémelin, J., Purify and destroy: The political uses of massacre and genocide, New York, Columbia University Press, 2007. 
Shilling, C., The body and social theory, London, Sage, 1993.

Spierenburg, P., A History of Murder: Personal Violence in Europe from the Middle Ages to the Present, Cambridge, Polity, 2008.

Spierenburg, P., Violence and Punishment: Civilizing the Body through Time, Cambridge, Polity, 2012.

Spierenburg, P., Dr. Van Reybrouck, I presume: Over Congo, cultuur en criminaliteit, Tijdschrift over Cultuur en Criminaliteit, 2013, 3, 1, pp. 84-92.

Tone, J. L., War and genocide in Cuba, 1895-1898, Chapel Hill, University of North Carolina Press, 2006.

Totten, S. Parsons, W.S., Century of genocide: Critical essays and eyewitness accounts, ( $3^{\text {rd }}$ edition) New York, Routledge, 2009.

White, M., The great big book of horrible things: The definitive chronicle of history's 100 worst atrocities, New York, W.W. Norton \& Company, 2012.

Zimmerer, J., Von Windhuk nach Auschwitz? Beiträge zum Verhältnis von Kolonialismus und Holocaust, Berlin, Lit Verlag, 2011. 